\title{
Příroda nás živí, země nás nese
}

\section{Jiří Olšovský}

\section{Envigogika 12 (1) - Inspirace/ Inspiration}

Publikováno / Published 23. 7. 2017

\section{DOI: $\underline{10.14712 / 18023061.546}$}

My civilizovaní lidé jsme stále dětmi země a přírody - země nás nese, príroda nás živí. Ze země čerpáme zdroje $\mathrm{k}$ životu, především životodárnou vodu, dále třeba kovy pro naše věci, jimiž si pomáháme $\mathrm{k}$ našemu dobrému žití na zemi. Plodiny země nás živí. I náš počítač je vytvořen z látek země. Uznejme tedy zemi jako jeden z živlů, pečujme o ni jako o ostatní živly, jako o vodu, jež nám zahání žízeň, o vzduch, který dýcháme, o půdu, po níž kráćíme a z níž rostou stromy a plodiny. Jsme děti země - a naučili jsme se zacházet i s ohněm, jenž nám poskytuje teplo a energii ve svých různých podobách, a možná za necelých 35 let zažehneme jadernou fúzi.

\section{Pohyb za obnovitelnými zdroji}

A tak bychom nyní neměli opouštět ideu obnovitelných zdrojů, abychom nemuseli psát jako český politolog Alexander Tomský (*1947): „Orné půdy ubývá, lidstva přibývá, kácení tropických lesů... poškozuje plíce planety...", roste eroze půdy a množství skleníkových plynů neklesá. Proto potřebujeme vskutku novou vizi pro národy i pro celý svět, hlubší filosofické zamyšlení. O zcela nové nasměrování a ryzí souznění celých společenství nyní jde, aby se nakonec našla nová aliance - autentické spojenectví člověka s př́rodou. Poněkud jsme se jako lidé od př́rody oddělili, ale nastal čas ke zcela uvědomělému příklonu $\mathrm{k}$ prírodě a k půdě, nebo nás sama skrytá moc prrírody zničí (mohli bychom dopadnout jako na Venuši). O př́rodu je proto třeba zcela novým zdravě konzervativním zpưsobem pečovat, aby nás príroda nakonec nevyplivla jak ničivou jedovatou pecku (jak se říká). Kdo bezhlavě poráží další a další stromy a lesy/pralesy, kdo pěstuje monokultury, si nic jiného nezaslouží. Kdo vybíjí žraloky jen pro jejich ploutve, slony a nosorožce pro jejich kly apod., aby se uspokojily scestné potřeby některých nerozumných a poživačných lidí, si nic jiného nezaslouží. Vưči prrírodě je zapotřebí rozvinout více pokory.

Cesta k celkově př́znivému biofilnímu využívání obnovitelných zdrojů bude jistě klopotná. Jen tak hned se nám nepodaři vytvořit ty nejlepší stroje na využívání sluneční, větrné, vodní a jaderné energie, ale jiná cesta není než zkoušet stále lepší a účinnější větrníky, sluneční a vodní elektrárny, které nakonec budou bytostně souznít s přírodou i s naším estetickým cítěním. Nové teorie vzejdou z původních meditací vědců a tvůrců, doposud oheň meditativního myšlení plane $v$ našem nitru, skrze nějž může zazářit pravda. Žádnému černému inkvizitorovi se nemůže podařit popř́t ty myslitele, kteří otevírají světlejší obzory pro lidský pobyt na zemi.

\section{Vymanit se z falešného optimismu}

Někteří dnes stále zatáatě myslí (je v tom značná porce dogmatismu), že člověk se svým průmyslem nijak „zásadně" nepřispívá k rostoucímu globálnímu oteplování, svádějí to 
na sluneční a kosmické cykly apod. Je to útěšný mýtus, který má člověka odvést od vyšší bdělosti vůči prrírodě směrem $\mathrm{k}$ blazeované spokojenosti: nic moc se přece ještě neděje, nějaký vzduch ještě dýcháme, technika zařídí, že budeme stále $v$ pohodě. Jsou to věční optimisté, a nad nimi ještě často bdí jakási útěšná prozřetelnost, že bůh to nakonec zvládne a neopustí nás. Tato myšlenka je též poněkud scestná, protože také člověka ukolébává v iluzi věčných optimistů, že když ne technika, tak bůh nás jen tak neopustí a všechno nakonec zařídí k naší plné spokojenosti. Zdravě konzervativní (tj. ochraňující) a realistický názor však nemůže být takto "jednoduše" a naivně optimistický. Samožrejmě nemůže být ani stejně jednoduše pesimistický, základní naděje by nás neměla opouštět. Technika nás vskutku nakonec, jak predikoval již německý fenomenologický filosof, ontolog a básník Martin Heidegger (1889-1976), může zachránit. Zachrání nás bytostná vděčnost před bytím samým.

Rys trvalé "věčnosti" (ovšem konečné) v sobě nese zajisté vesmír v celku, a tak k němu upíráme svou budoucí naději, naději odvážných tvůrců-vesmiřanů, kteří budou z vlastních meditací a hlubokých zamyšlení otevírat příznivé obzory pro člověka, pobývajícího zde na Zemi. Zatím také můžeme pěstovat svůj moudrý a biofilní vztah k prírodě a ke všem jejím živlům. Nechme se jimi prostupovat, jen tak s nimi můžeme mít zkušenost, jež nás ponoukne a nakonec přiměje $k$ jejich ochraně a prozřetelné péči o ně. Nelze pečovat jen o sebe - což bývá často pouhým nezřízeným egoismem -, je zapotřebí se náležitě starat i o své okolí, o zemi, o všechny živly, které nesou svět a jimiž tryská bytí samo. Dnes pečovat o sebe znamená pečovat i o tebe, prírodo, abys nezdevastována opět ožívala, mohla žít dál $\checkmark$ niterném souručenství $s$ námi, kteří se probouzejí zde na zemi ke své stále obnovené citlivosti $k$ tobě.

\section{Mimo optimismus a pesimismus}

$\checkmark$ našem lidském zájmu je dnes překonávat hrubý antropocentrismus a voluntarismus vưči přírodě a jiným bytostem (včetně velryb, Ivů, korálů, stromů aj.), hledat pravé společenství i s mimolidskými bytostmi, být tak $v$ jednotě s celkem př́rodního bytí a kosmu. Jen tak se Ize prolamovat $k$ dobrému živobytí - cestou udržitelného hospodaření, cestou neutuchajícího vědeckého snažení. Tato cesta by se měla dít mimo falešný optimismus i pesimismus. Apokalyptika života se nás bude sice vždy dotýkat, mohutné supersopky mohou kdykoli vybuchnout, planetka či asteroid mohou kdykoli přiletět, měsíc nám jednou odletí, zeměkoule se může kdykoli přepólovat apod. I politika může zdivočet a bude záležet na tom, zda se dopředu budou dostávat vskutku vzdělaní a odpovědní lidé masarykovského typu. Tento typ vzchází jednak z hlubokého ponoření do sebe, kdy nahmatáváme sebe sama a jsme $s$ to, jak ř́kal německý filosof, fenomenolog, moravský rodák Edmund Husserl (1859-1938), dokonce vycitóvat a nalézat svou transcendentální subjektivitu, z níž jedině může prýštit pravdivé poznání světa, sebe a druhých. Jednak půjde o opětný návrat ke světu, vnímat ho realisticky a prakticky, přičemž se mohou zjevovat, jak nám ukázali fenomenologičtí myslitelé typu Jana Patočky (1907-1977) a Martina Heideggera, i zjasněné existenciálně-ontologické možnosti našeho pobytu na zemi, kdy jsme $s$ to spět ke svým vrcholkům, k hranicím svých možností - v naladění na živoucí bytí.

S překonáváním agresivního přistupu ke světu a přírodě i sobě samým může být dál kultivována myšlenka udržitelného života - udržet život na Zemi nejen tisíc let, ale ještě mnohem déle. Půjde o změnu našeho postoje ke světu a př́rodě, také náš kapitalismus bude muset být mnohem „něžnější", kdy ekosystémy (a člověk s nimi) nebudou trpět pod dusotem tupě dopadajících kopyt nijak neregulovaného (arogantního) kapitalismu. Bude třeba nového zamyšlení, jež se zeleně-heideggerovsky zbaví nenasytného chtění a bezbřehého ziskuchtivého dobývání, jež vede k brzkému konci. Tehdy necháme-být-jsoucno, aby si žilo svým 
přirozeným a svobodným životem, vzdáme se různých sociálně-inženýrských aktivismů (včetně různých multikulti-neomarxismů) a odevzdáme se pravým pramenům života, ryzím počátkům bytí.

\section{Důvěřovat realitě}

Český filosof a ekosof Erazim Kohák (*1933) také píše o lidské schopnosti „přijmout přítomnost reality $v$ její bezprostřednosti". Jde o ničím nezprostředkovanou účast na životě, na přítomném dění, kdy nediskurzivně participujeme na přirozenosti bytí. Tato naše účast může být pravdivá a opravdová, jen tak Ize dosáhnout uvědomění toho, že nakonec nebudeme svévolně ničit naši skutečnost (realitu), budeme ji naopak náležitě biofilně kultivovat a obnovovat. Náš domov, naše bytí lze láskyplně opečovávat. Jen tehdy může zasvitnout i kousek posvátné reality nebes, onen "svatý oheň", na který jsou schopni se ladit básníci (jako německý básník a myslitel Friedrich Hölderlin, žijící v letech 1770-1843), a skuteční myslitelé typu Patočky a Heideggera. Tak je kýžený ideál stále př́tomný $\mathrm{i} v$ naší realitě, může prosvítat naší smysluplnou činností, na našich "světelných mýtinách" můžeme v záblescích zakoušet pravdu bytí.

Tato pravda dál prozařuje naší skutečností. Půjde o to živě a účinně pěstovat svůj realismus navzdory upadlosti světa pokleslých médií a zúředničtělých (evropských) politiků. Také filosofové se mohou učit větší pokoře při stupňování svého poznání. Nenasytní inkvizitoři mezi nimi (stále existují) by měli být vymycováni světlem skutečných a osvícených mýtin, vysmoleni jak nepěkní všežraví černočerní brouci, kteří si libují v pouhé negaci, v popírání myslících opravditelů.

Pravda světa, pravda bytí se nám může stále ukazovat, půjde o to nepodléhat sugescím domněle postpravdivé skutečnosti, fatalismu falešného determinismu, různým vyumělkovaným spekulacím a zlovolným konstrukcím dneška. Základní realitou zůstává príroda a dějící se dějiny, v nichž se odehrávají naše procitající životy. Z možné upadlosti našich životů a z odcizenosti prírodě se Ize zvedat, procitat z deformované skutečnosti, otevírat se obrazům pravého bytí. 